\title{
SIKAP MOTIVASI DAN MINAT BERWIRAUSAHA MAHASISWA FAKULTAS PETERNAKAN UNIVERSITAS UDAYANA
}

\author{
N. L. G. Sumardani ${ }^{1}$, B. R. T. Putri ${ }^{2}$, dan A. A. P. P. Wibawa ${ }^{3}$
}

\begin{abstract}
ABSTRAK
Sikap, motivasi dan minat sangat dibutuhkan bagi mahasiswa yang berwirausaha agar mampu mengidentifikasi peluang usaha, serta mendayagunakan peluang usaha untuk menciptakan peluang kerja baru. Kegiatan yang dilaksanakan di Fakultas Peternakan Universitas Udayana bertujuan untuk mengetahui apakah sikap dan motivasi dapat meningkatkan minat mahasiswa dalam berwirausaha. Metode yang digunakan adalah simple random sampling survey dengan pendekatan analisis deskritif kuantitatif. Data dikumpulkan dengan metode kuisioner dan diolah menggunakan program SPSS. Analisis data menggunakan regresi linier. Dari hasil kegiatan ini menunjukkan bahwa sikap dan motivasi berpengaruh signifikan terhadap minat berwirausaha, sehingga perlu adanya kegiatan pelatihan kewirausahaan dalam usaha meningkatkan hal tersebut.
\end{abstract}

Kata kunci : sikap, motivasi, minat, wirausaha, mahasiswa.

\begin{abstract}
Attitudes, motivations and interests are needed for students who are entrepreneurial in order to be able to identify business opportunities, and create new employment opportunities. The activity at the Faculty of Animal Husbandry at Udayana University aims to find out whether attitudes and motivations can increase student interest in entrepreneurship. The method used is simple random sampling survey with a quantitative descriptive analysis approach. Data was collected by questionnaire and processed using the SPSS program. Data analysis using linear regression. From the results of this activity shows that attitudes and motivation have a significant effect on the interest in entrepreneurship, so the need for entrepreneurial training activities in an effort to improve it.
\end{abstract}

Keywords: attitudes, motivation, interests, entrepreneurship, students.

\section{LATAR BELAKANG}

Wirausaha menurut Agustina dan Sularto (2011) adalah orang yang menciptakan sebuah bisnis yang berhadapan dengan risiko dan ketidakpastian, yang bertujuan untuk memperoleh profit, dan mengalami pertumbuhan dengan cara mengidentifikasikan kesempatan dan memanfaatkan sumberdaya yang diperlukan. Sedangkan pengusaha atau wirausahawan (entrepreneur) menurut Sumardi (2017) adalah seorang yang menciptakan sebuah usaha atau bisnis yang diharapkan, dengan risiko dan ketidakpastian, untuk memperoleh keuntungan dan mengembangkan bisnis dengan cara membuka kesempatan.

\footnotetext{
${ }^{1}$ Fakultas Peternakan Universitas Udayana,nlg_sumardani@unud.ac.id

${ }^{2}$ Staf pengajar Fakultas Peternakan Universitas Udayana, tanamaputri@unud.ac.id

${ }^{3}$ Staf pengajar Fakultas Peternakan Universitas Udayana, aputrawibawa@unud.ac.id
} 
Pada saat ini di Indonesia terdapat sebanyak 128,06 juta orang angkatan kerja, sebanyak 121,02 juta orang merupakan penduduk bekerja dan 7,04 juta orang pengangguran. Berdasarkan pendidikan, tingkat pengangguran terbuka terendah berada di jenjang pendidikan sekolah dasar kebawah yakni 3,54\%, Sekolah Menengah Pertama (SMP) sebesar 5,36\%, Sekolah Menengah Atas (SMA) Sebesar 7,03\%. Sekolah Menengah Kejuruan (SMK) 9,27\%. Diploma III (D3) sebesar $6,35 \%$, dan perguruan tinggi (universitas) sebesar 4,98\%. (BPS, 2017).

Meskipun jumlah pengangguran tingkat sarjana lebih kecil daripada jumlah pengangguran lulusan SMP, dan SMA, namun data dari Badan Pusat Statistik menunjukkan bahwa angka sarjana yang menganggur di Indonesia dalam tiga tahun terakhir terus mengalami peningkatan. Pada bulan Pebruari 2014 jumlah pengangguran tingkat sarjana mencapai 398 ribu jiwa, di bulan Februari 2015 mengalami kenaikan mencapi 565 ribu jiwa dan pada tahun 2016 meningkat 20\% menjadi 695 ribu jiwa (BPS, 2017).

Berdasarkan data yang ada, terlihat bahwa generasi muda lulusan perguruan tinggi masih berorientasi sebagai job seeker dan bukan sebagai job maker. Oleh karena itu sangat diperlukan adanya penanaman jiwa wirausaha melalui pemberian matakuliah kewirausahaan di Universitas, serta berbagai pelatihan maupun lomba yang bertujuan untuk meningkatkan jiwa wirausaha mahasiswa. Setelah menamatkan studinya, diharapkan mahasiswa mempunyai bekal yang cukup untuk memulai usaha sehingga mampu mengurangi jumlah pengangguran. Selain berwirausaha dapat mengurangi pengangguran, lulusan universitas dapat bersaing di dunia kerja.

Sikap, motivasi dan minat mahasiswa sangat dibutuhkan bagi mahasiswa yang berwirausaha agar mampu mengidentifikasi peluang usaha, serta mendayagunakan peluang usaha untuk menciptakan peluang kerja baru. Motivasi merupakan dorongan dari dalam diri seseorang yang mendorong orang tersebut untuk melakukan sesuatu, termasuk menjadi young entrepreneur (Sarosa, 2005). Baum et al. (2007) menyatakan bahwa motivasi dalam kewirausahaan meliputi motivasi yang diarahkan untuk mencapai tujuan kewirausahaan, seperti tujuan yang melibatkan pengenalan dan eksploitasi terhadap peluang bisnis. Minat menjadi wirausaha merupakan keinginan seseorang untuk bekerja mandiri, menjalankan usahanya sendiri (self employed). Minat mahasiswa menjadi wirausaha menurut Budiati et al. (2012) dibagi dalam empat kelompok yaitu: 1) Minat memulai wirausaha dalam jangka waktu dekat; 2) Minat memulai wirausaha dua tahun mendatang; 3) Minat memulai wirausaha untuk jangka panjang; dan 4) Tidak memiliki minat berwirausaha.

Dalam rangka mengembangan kewirausahaan di perguruan tinggi menuju terbentuknya wirausaha baru di Fakultas Perternakan Universitas Udayana maka dikembangkan program pengembangan kewirausahaan (PPK) melalui Hibah Direktorat Riset dan pengabdian Masyarakat Kemenristek Dikti. Menurut Sardiana, dkk (2015), fungsi utama program kewirausahaan di perguruan tinggi adalah melakukan kegiatan inkubasi melalui pembinaan, bimbingan, dan pendampingan serta fasilitasi manajemen, teknologi, permodalan dan pemasaran terhadap potensi bisnis mahasiswa sehingga menjadi unit bisnis yang mandiri. Tulisan ini membahas tentang pengaruh sikap, motivasi dan minat mahasiswa terhadap minat mahasiswa menjalankan wirausaha di fakultas Peternakan Universitas Udayana.

\section{METODE PEMECAHAN MASALAH}

Metode yang digunakan dalam pemecahan masalah ini melalui metode survei kualitatif dan kuantitatif. Kegiatan dilaksanakan di Fakultas Peternakan Universitas Udayana, dari bulan April sampai September 2018. Populasi atau keseluruhan pengamatan yang menjadi perhatian penelitian ini adalah mahasiswa Fakultas Peternakan Universitas Udayana, semester V dan VII, karena pada semester ini mahasiswa telah mendapatkan materi tentang kewirausahaan. Rancangan yang digunakan pada kegiatan ini adalah survei, yaitu metode kualitatif menekankan pada aspek 
pemahaman secara mendalam terhadap suatu masalah daripada melihat permasalahan untuk penelitian generalisasi, sedangkan metode kuantitatif adalah metode pengukuran yang menekankan pada aspek pengukuran secara objektif terhadap fenomena sosial. Data kuantitatif merupakan data yang dinyatakan dalam bentuk angka-angka, dan dibantu dengan kuesioner. Responden mahasiswa ditentukan menggunakan metode simple random sampling. Sebanyak 100 orang sampel diambil secara acak dari masing-masing semester (V dan VII), sehingga total responden sebanyak 200 orang. Minat mahasiswa menjadi wirausaha dibagi dalam empat kelompok yaitu: 1) Minat memulai wirausaha dalam jangka waktu dekat; 2) Minat memulai wirausaha dua tahun mendatang; 3) Minat memulai wirausaha untuk jangka panjang; dan 4) Tidak memiliki minat berwirausaha.

Analisis data menggunakan metode analisis deskriptif kuantitatif, yang berusaha memberikan secara sistematis dan cermat fakta-fakta aktual dan sifat populasi tertentu. Dalam hal ini hanya menjelaskan, memaparkan, dan menggambarkan secara objektif data yang diperoleh dan data yang sudah terkumpul untuk memperoleh jawaban dari masalah.

\section{HASIL DAN PEMBAHASAN}

Kegiatan ini bertujuan untuk mendapatkan gambaran sikap, motivasi dan minat mahasiswa untuk menjalankan wirausaha dan mengelola wirausaha. Kegiatan ini dilakukan juga untuk mengetahui apakah sikap dan motivasi berwirausaha berpengaruh signifikan terhadap minat mahasiswa berwirausaha. Sejumlah 200 mahasiswa digunakan sebagai sumber data dalam penelitian ini. Minat mahasiswa menjadi wirausaha dibagi dalam empat kelompok yaitu: 1) Minat memulai wirausaha dalam jangka waktu dekat; 2) Minat memulai wirausaha dua tahun mendatang; 3) Minat memulai wirausaha untuk jangka panjang; dan 4) Tidak memiliki minat berwirausaha. Hasil survei menunjukkan bahwa sikap, motivasi dan minat mahasiswa berwirausaha sangat bervariasi seperti terlihat dalam Tabel 1. berikut ini:

Tabel 1. Sikap, Minat, dan Motivasi Berwirausaha Fapet UNUD

\begin{tabular}{lccc}
\hline Kriteria & SMT V $(\%)$ & SMT VII (\%) & Rataan (\%) \\
\hline Jangka Pendek & 12 & 25 & 18 \\
Dalam 2 tahun & 58 & 48 & 53 \\
Jangka Panjang & 25 & 20 & 23 \\
Tidak ada minat & 5 & 7 & 6 \\
\hline
\end{tabular}

Sumber: survei pada mahasiswa Fapet UNUD (2018)

Hasil uji hipotesis menghasilkan bahwa $\mathrm{F}$ hitung $\geq \mathrm{F}$ Tabel $=\mathrm{H} 1$ diterima, artinya variabel sikap, motivasi dan minat berwirausaha berpengaruh nyata terhadap minat mahasiswa berwirausaha. Hal ini dikarenakan sampel mahasiswa yang disurvei telah mendapatkan ilmu kewirausahaan dan kegiatan pelatihan kewirausahaan, sehingga hal tersebut dapat mendorong minat dan motivasi mahasiswa untuk berwirausaha.
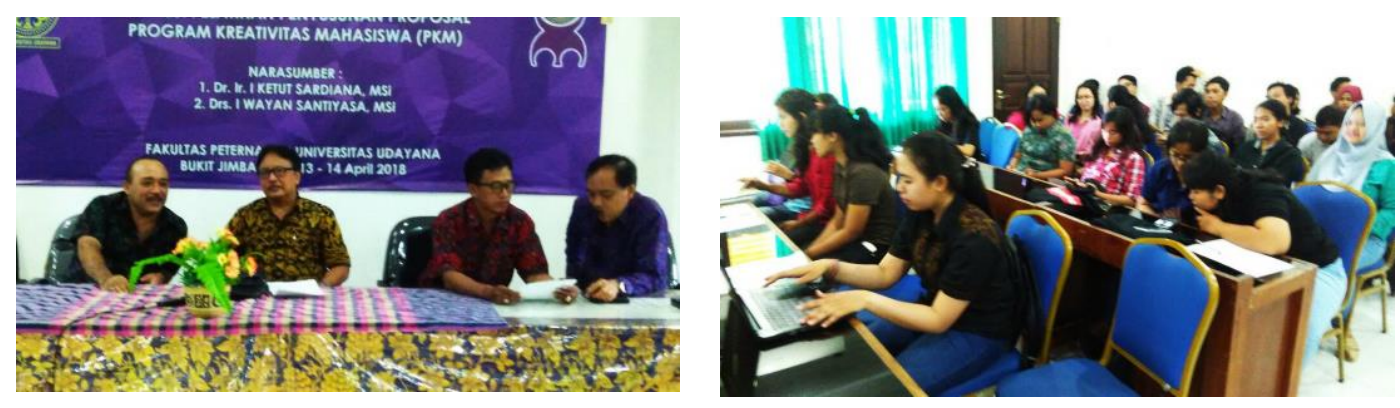
Gambar 1-2. Kegiatan pelatihan kewirausahaan merupakan salah satu usaha yang dilakukan di Fakultas Peternakan Universitas Udayana dalam meningkatkan minat dan motivasi mahasiswa.

(Dokumentasi pribadi, 2018)

Minat adalah kecenderungan terhadap sesuatu yang timbul karena dorongan dari dalam diri maupun rangsangan dari lingkungan (Noeng Muhadjir, 1996). Minat adalah perasaan tertarik atau berkaitan pada suatu hal atau aktivitas tanpa ada perintah dari pihak lain (Tarmudji, 1991). Pernyataan ini diperkuat dengan teori Mappiare (1982) yang menyatakan bahwa dengan adanya minat dapat mendorong individu untuk mendekati objek yang disenanginya dan dikerjakannya sehingga pekerjaan yang dilakukan akan menjadi lebih baik. Wirausaha merupakan orang yang berjiwa berani mengambil resiko untuk membuka usaha dalam berbagai kesempatan. (Kasmir, 2007). Minat wirausaha adalah usaha seseorang untuk memenuhi kebutuhan hidup tanpa ada rasa ketergantungan kepada orang lain dan selalu yakin akan keberhasilan, hal ini tercermin dari sikap pantang menyerah dan selalu ingin belajar dari kegagalan yang dialami (Yanto 1996). Minat wirausaha tersebut tidak hanya keinginan dari dalam diri saja tetapi harus melihat ke depan dalam potensi mendirikan usaha.

Adapun faktor-faktor yang menjadi melatar belakangi karakter seorang wirausaha adalah: Faktor 1) Kepribadian, merupakan keterpaduan antara aspek-aspek kepribadian yang meliputi aspek psikis seperti kecerdasan, sikap, bakat, minat, motif, kemampuan, moral dan aspek jasmaniah seperti postur tubuh, tinggi dan berat badan, indra, dan sebagainya (Sukmadinata, 2004). Sedangkan menurut Mouly (1973) mendefinisikan kepribadian sebagai keseluruhan dari kondisi fisik, mental dan emosional yang menyatu menjadi karakteristik individu yang unik dan khas sehingga memiliki perbedaan dengan individu yang lainnya. Kepribadian seseorang tidak persis sama dengan kepribadian orang lain. Menurut Buchari Alma (2007) kepribadian yang mendukung seorang wirausaha adalah kepribadian yang produktif dimana orang tersebut memiliki sifat senang berinteraksi, bergaul, toleransi, terbuka sesama teman, memiliki rasa empati, dan suka menolong orang lain yang membutuhkan pertolongan.

Faktor 2) Lingkungan keluarga, terutama orang tua memiliki peran penting untuk masa depan anaknya sehingga secara tidak langsung dapat mempengaruhi pekerjaan anaknya di masa depan misalnya menumbuhkan minat anaknya untuk berwirausaha. Menurut Yusuf (2012) lingkungan keluarga memiliki peranan penting dalam menumbuhkan minat berwirausaha. Orang tua yang memiliki usaha akan besar pengaruhnya bagi anak untuk berwirausaha. Oleh karena itu, dorongan dan motivasi dari keluarga sangat penting untuk menumbuh kembangkan seorang anak untuk menjadi seorang wirausahawan yang sukses. Sebagaimana yang dinyatakan oleh Alma (2011) menyatakan bahwa lingkungan dalam bentuk role models yaitu dari lingkungan keluarga dari orang tua, saudara, teman, pengusaha sukses yang diidolakannya berpengaruh terhadap minat berwirausaha.

\section{SIMPULAN}

Dari kegiatan ini dapat disimpulkan bahwa sikap dan motivasi berpengaruh signifikan terhadap minat berwirausaha pada mahasiswa semester V dan VII di Fakultas Peternakan Universitas Udayana, serta kegiatan pelatihan kewirausahaan merupakan salah satu usaha yang dapat dilakukan di fakultas dalam meningkatkan minat dan motivasi mahasiswa.

\section{UCAPAN TERIMAKASIH}

Penulis menyampaikan terima kasih dan penghargaan kepada Direktorat Riset dan Pengabdian Masyarakat Kementrian Riset, Teknologi, dan Pendidikan Tinggi atas dana yang diberikan untuk Pelaksanaan Program Pengembangan Kewirausaan ini.

\section{DAFTAR PUSTAKA}


Agustina, C. \& Sularto, L. 2011. Intensi kewirausahaan mahasiswa (Studi perbandingan antara fakultas Ekonomi dan Fakultas Ilmu Komputer). Proceeding PESAT (Psikologi, Ekonomi, Sastra, Arsitektur, \& Sipil) Universitas Gunadarma, Depok, 18-19 Oktober 2011, 4: E.63-E.69

Alma, B. 2011. Kewirausahaan untuk Mahasiswa dan Umum. Alfabeta. Bandung.

Baum, J. R., Frese, M., \& Baron, R. A. 2007. The psychology of entrepreneurship. Mahwa, New Jersey: Lawrence Erlbaum Associates.

Badan Pusat Statistik. 2017. Pengangguran Terbuka 2017. BPS Nasional. Jakarta.

Budiati, Y., Yani, T. E., \& Universari, N. 2012. Minat mahasiswa menjadi wirausaha (studi mahasiswa Fakultas Ekonomi Universitas Semarang). Jurnal DINAMIKA SOSBUD, 14(1), 89-101.

Kasmir. 2007. Kewirausahaan. PT Raja Grafindo. Jakarta.

Mappiare, A. 1982. Psikologi Remaja. Usaha Nasional. Surabaya.

Noeng Muhadjir. 1996. Metodologi Penelitian Kualitatif. Rakesarisin. Yogyakarta.

Sarosa, P. 2005. Kiat Praktis membuka usaha. Be-coming young entrepreneur: Dream big start small, act now! Panduan praktis \& motivasional bagi kaum muda dan mahasiswa. Jakarta: PT Elex Media Komputindo.

Sardiana, I.K., B.R.T. Putri, I.G. Suranjaya, N.L.R. Purnawan. 2015. Pengembangan Kewirausahaan Di Universitas Udayana. Majalah Aplikasi Ipteks Ngayah : Vol. 6, No. 1, pp. 91-101.

Sukmadinata, N. S. 2004. Landasan psikologi proses pendidikan. PT. Remaja Rosdakarya. Bandung.

Sumardi, K. 2007. Menakar jiwa wirausaha mahasiswa teknik mesin angkatan 2005. Jurnal Pendidikan Teknologi Kejuruan, IV (10).

Tarmudji. 1991. Aspek Dasar Kehidupan Sosial. Liberty. Yogyakarta.

Yanto. 1996. Peluang kerja dan minat berwiraswasta di kalangan siswa Sekolah Teknologi Menengah Negeri Pembangunan Pekalongan (Laporan Penelitian). IKIP Semarang. Semarang.

Yusuf, S. 2012. Perkembangan Peserta Didik. PT. Raja Grafindo Persada. Jakarta. 